\title{
Survey of Physical Fitness Level for Elementary and Junior High School Student in Palembang
}

\author{
Iyakrus \\ Physical Education Study Program \\ Sriwijaya University \\ Palembang, Indonesia \\ iyakrusanas@yahoo.com
}

\begin{abstract}
This study aims to determine the physical fitness level of elementary and junior high school students in Palembang. This study was a descriptive study; the method used is survey method with test and measurement techniques. The samples are 46 elementary school students from grades 5 and 6 aged 10-12 years and 46 junior high school students aged 13-15 years in Palembang. The instrument used in this study is using the bleeP Physical Freshness test. Data analysis techniques using quantitative descriptive analysis. The result showed that the physical fitness level of elementary and junior high school students in Palembang are: $2.08 \%$ is excellent, $4.16 \%$ is good, $4.16 \%$ is average, $8.33 \%$ is fair, and $81.25 \%$ are poor. the physical fitness level of elementary and junior high school students in Palembang are: $8.69 \%$ is excellent, $4.35 \%$ is good, $23.91 \%$ are average, 8.69 $\%$ is fair, $54.35 \%$ are poor. Based on the test results, we can conclude that the physical fitness of elementary school students in Palembang categorized poor, while the junior high school student physical fitness category fair. It is suggested to each school both elementary and junior high school can improve the physical fitness of students with extracurricular activities in accordance with the interests of students at least 3 times a week.
\end{abstract}

Keywords—physical fitness; elementary school students; junior high school students

\section{INTRODUCTION}

Physical education in elementary and junior high schools emphasizes exploration, choice, and creativity to develop motor skills effectively and efficiently through physical activity. In the Curriculum 2013, physical and health education in primary education prepares more complex and dynamic child development, for which physical education in schools with emphasis on exploration, choice, and creativity to develop motor skills effectively and efficiently through physical activity for physical fitness.

Children at school age in physical education are expected to move more with regular physical activity. Sensory stimulation at an early age is important for developing basic skills, analytical skills and may even be an intermediary factor that enables rapid learning in the adult stage to respond to exercise. [1] opinion, physical education is an educational process that involves the interaction of learners with an environment that is managed through physical activity systematically toward the formation of a complete human being.

According to [2], Physical Education is more emphasis on the results of skills and performance than to take into account the needs of students as a subject learn as it has been so far in the field. Furthermore, according to [3], physical education is an educational process that utilizes physical activity to produce a holistic change in the quality of the individual, both physically, mentally and emotionally, and treats the child as a whole with a good physical fitness.

Physical education teachers should first be able to manage the learning of physical education not only leads to ability and skill course but more oriented to fulfill a requirement of student movement which is more appreciative and recreative in order to increase the physical freshness of student. One of the goals of physical education in schools is to improve students' physical fitness, therefore physical education teachers should be able to improve the physical fitness of their students. Some research results show that physical fitness of elementary and junior high school students is low, such as research result of [4] $60 \%$ of elementary school students in Jambi have physical fitness in less category, then [5] research result $40 \%$ female students of Elementary School 36 Sungai Raya district Kubu Raya in the less category.

With regard to the results of the above research, the purpose of this study was to determine the physical fitness level of elementary school students and junior high school students in Palembang, South Sumatra. By knowing the level of physical fitness of elementary and junior high school students in Palembang is a guideline for teachers of Physical Education to be able to manage Physical Education in schools in order to improve the physical fitness of their students.

\section{METHODS}

This research is a quantitative descriptive study of using survey research methods to see aerobic endurance (VO2max) level and using data collecting technique with bleep test. In this study will get aerobic endurance (VO2max) level of elementary and junior high school students as a reference in preparing the teaching and learning activities. This research was conducted in Palembang with the research held in October - November 2016 with a total sample 92 people consisting of 46 elementary schools and 46 junior high school students in Palembang. The collected data were analyzed statistically using score then calculated by a category level aerobic endurance (VO2 max). 


\section{RESULTS AND DISCUSSION}

This result gets the data of physical fitness level from elementary and junior high school students in Palembang. Data from the physical fitness test for students of Elementary School in Palembang can be seen in Table I and Fig. I below.

TABLE I. DATA DESCRIPTION OF PHYSICAL FRESHNESS TEST FOR ELEMENTARY SCHOOL STUDENT IN PALEMBANG

\begin{tabular}{|c|c|c|c|c|c|c|c|}
\hline \multirow{2}{*}{$\begin{array}{l}\mathbf{N} \\
\mathbf{0}\end{array}$} & \multirow{2}{*}{$\begin{array}{l}\text { Table } \\
\text { Head }\end{array}$} & \multicolumn{5}{|c|}{ Table Column Head } & \multirow{2}{*}{$\begin{array}{c}\text { De } \\
\text { s }\end{array}$} \\
\hline & & $\begin{array}{c}\text { Excellen } \\
t\end{array}$ & Good & $\begin{array}{c}\text { Averag } \\
e\end{array}$ & Fair & Poor & \\
\hline 1 & $\begin{array}{l}\text { Physical } \\
\text { Freshness } \\
\text { Test }\end{array}$ & 1 & 2 & 2 & 4 & 39 & 48 \\
\hline 2 & $\begin{array}{c}\text { Percentag } \\
\text { e }\end{array}$ & $2,08 \%$ & $\begin{array}{c}4,16 \\
\%\end{array}$ & $4,16 \%$ & $\begin{array}{c}8,33 \\
\%\end{array}$ & $\begin{array}{c}81,25 \\
\%\end{array}$ & \\
\hline 3 & Mean & 57 & 46,5 & 40 & 38,5 & 17,13 & \\
\hline
\end{tabular}

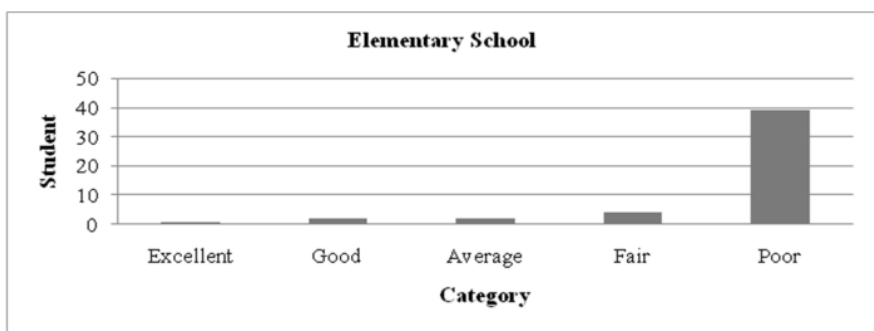

Fig. 1. The results of Physical Fitness Test for Elementary School in Palembang

In Table I and Figure 1 above can be seen the test results, 1 $(2.08 \%)$ student with an excellent category, $2(4.16 \%)$ student with a good category, 2 (4.16\%) student with an average category, $4(8.33 \%)$ student with a fair category, and 39 $(81.25 \%)$ student with a poor category. Data from the physical fitness test for students of Junior High School in Palembang can be seen in Table II and Fig. 2 below.

TABLE II. DATA DESCRIPTION OF PHYSICAL FRESHNESS TEST FOR JUNIOR HIGH SCHOOL STUDENT IN PALEMBANG.

\begin{tabular}{|c|c|c|c|c|c|c|c|}
\hline \multirow{2}{*}{$\begin{array}{c}\text { N } \\
\text { o }\end{array}$} & Table & \multicolumn{5}{|c|}{ Table Column Head } & \multirow{2}{*}{$\begin{array}{c}\text { De } \\
\text { Head }\end{array}$} \\
\cline { 3 - 7 } & $\begin{array}{c}\text { Excellen } \\
\boldsymbol{t}\end{array}$ & Good & $\begin{array}{c}\text { Averag } \\
\boldsymbol{e}\end{array}$ & Fair & Poor & S \\
\hline 1 & $\begin{array}{c}\text { Physical } \\
\text { Freshness } \\
\text { Test }\end{array}$ & 4 & 2 & 11 & 4 & 25 & 46 \\
\hline 2 & $\begin{array}{c}\text { Percentag } \\
\text { e }\end{array}$ & $2,08 \%$ & $\begin{array}{c}4,16 \\
\%\end{array}$ & $4,16 \%$ & $\begin{array}{c}8,33 \\
\%\end{array}$ & $\begin{array}{c}81,25 \\
\%\end{array}$ & \\
\hline 3 & Mean & 57 & 46,5 & 40 & 38,5 & 17,13 & \\
\hline
\end{tabular}

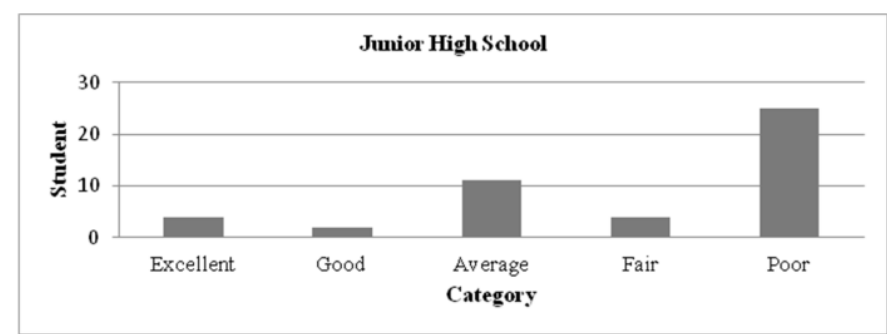

Fig. 2. The results of Physical Fitness Test for Junior High School in Palembang
In Table 2 and Figure 2 above can be seen the test results, 4 $(8.69 \%)$ student with an excellent category, $2(4.35 \%)$ student with a good category, $11(23.91 \%)$ student with an average category, $4(8.69 \%)$ student with a fair category, and 25 (54.35 $\%)$ student with a poor category. From the data frequency distribution table 2 above can be described into the histogram below.

Based on the results of tests that have been conducted, showed that the physical fitness level of elementary school students in Palembang are in poor category with $81.25 \%$, while the physical fitness level of junior high school students in Palembang are in poor category with $54.35 \%$, therefore can be concluded that the physical fitness level of elementary and junior high school students in Palembang both of them are in poor category.

According to [6], the main in maintaining the aerobic endurance (VO2max) level is with do physical activity repeatedly and increases the resistance to increase strength, speed, flexibility and muscle endurance, physical activity is also aimed at achieving a biological adjustment so that the activity can be displayed optimally. Physical activity at the level of aerobic endurance (VO2max) is a major component in preparing a child's body to face the daily activities [7].

System energy metabolism aerobically sourced from carbohydrates, fats and also from the breakdown of proteins that produce energy, which is used at the time of exercise is resistance, which requires a fairly long duration [8]. Therefore, students who perform physical activity should have good capability to supply oxygen to the body in order the process of energy metabolism aerobically can walk perfectly.

\section{CONCLUSION}

Laboratory tests have high accuracy but to conduct these tests required a high cost and not everyone has this assay as compared to use field tests. One test aerobic endurance (VO2 $\max$ ) that can be used in the field is a multistage fitness test or tests bleep.

Analysis of test research on the 46 elementary schools in Palembang can be concluded that the level of aerobic endurance (VO2 max) of elementary school students as follows: 14 student with an excellent category, 19 student with a good category, 0 student with an average category, 5 student with a fair category, and 5 student with a poor category, then the level of aerobic endurance (VO2 max) junior high school students as follows: 4 student with an excellent category, 2 student with a good category, 11 student with an average category, 4 student with a fair category, and 25 student with a poor category. It is in line with the results of the study Physical Freshness Center National Education Ministry [10] that the learning outcomes of physical education in elementary school are generally only able to give the effect of physical fitness at least 15 percent of the overall student population. Meanwhile, in a simple search through the test Sports Search in related aspects physical fitness of high school students, students in Indonesia on average only reached the category of "Low" [9].

The results of this study did not take into consideration other factors that affect a person's physical health, such as genetics, body temperature, and health status. Additionally, this research 
is only done on a special group that is aged 12-15 years conducted in the field. Therefore, to get the results more convincing in its use needs to be done for further research.

Based on the above results we can conclude several things related to teaching in schools both in an elementary school and in Junior High School such as research [10] and [11] the implementation of learning physical education and health in schools, teachers more emphasis on a) satisfy the desire to move in accordance with the basic skills, b) stimulate the growth and development of physical and motor development, c) maintain and improve health and physical fitness, d) instill discipline, teamwork, sportsmanship, and follow the rules and regulations e) increase endurance, prevent and cure a disease.

Learning health and physical education in schools, especially at the elementary and junior high school in order run properly for improving physical fitness, it can be suggested as follows:

- Aerobic endurance (VO2 max) primary school and junior high school needs to be improved through improving the physical activity and extracurricular activities at the school.

- The addition of PE hours either in elementary school or junior high school needs to be adapted to the needs and increased levels of aerobic endurance (VO2 max) of students in the school.

\section{REFERENCES}

[1] Cholik. T, "Pendidikan Jasmani dan Kesehatan," Jakarta: Proyek Pengembangan Guru SD, 2009.

[2] Mahendra. Agus, "Implementasi Movement-Problem-Based Learning Sebagai Pengembangan Paradigma Reflective Teaching Dalam Pendidikan Jasmani: Sebuah Community-Based Action Research Di Sekolah Menengah Di Kota Bandung," Bandung: Indonesia Education University, 2006.

[3] Karen. W, Bridges, and M.Jennifer, "Teaching Movement Education," Human Kinetics, 2010.

[4] Asrar. RM, "Analisis Tingkat Kebugaran Jasmani Siswa Sd Islam Terpadu Nurul Ilmi Kota Jambi,” 2013.

[5] Affandi. V G, "Survei Tingkat Kebugaran Jasmani Dengan Menggunakan Tes Kebugaran Jasmani Indonesia Pada Siswa Sekolah Dasar,” 2014

[6] Bompa, "Theory and Methodology of Training," United States: Human Kinetics, 2009.

[7] Iyakrus, "Pengembangan Komponen Fisik Sepaktakraw," unpublish, 2013.

[8] Brown. Travis, M. S, and D, CSCS, "Speed and Agility: What Defines them an How to Train for Both," Performance Training Jurnal, vol. 8.

[9] Andi. A, "Menggagas Kurikulum Pendidikan Jasmani yang Seimbang dan Efektif dengan Orientasi Masa Depan," Sport Coach Faculty of UNM, 2016.

[10] Shephard. JR, "Physical Education, School Physical Activity, Schoo Sports And Academic Performance," International Journal of Behavioral Nutrition and Physical Activity 2008, pp. 5-10, 2008.

[11] McEvory. Erin and BSR, "An Integrated Curriculum Approach to Increasing Habitual Physical Activity in Children: A Feasibility Study," Journal School Health, vol.76, pp 74-79, February 2006. 